\title{
The pulmonary blood volume measured by cardiovascular magnetic resonance imaging - relation to cardiac pumping and anthropometric measures
}

\author{
Andreas Fredholm*, Mikael Kanski², John Maret-Ouda ${ }^{1}$, Magnus Lundin ${ }^{1}$, Peder Sörensson ${ }^{1}$, Håkan Arheden², \\ Martin Ugander ${ }^{1}$
}

From 17th Annual SCMR Scientific Sessions

New Orleans, LA, USA. 16-19 January 2014

\section{Background}

Non-invasive quantification of the pulmonary blood volume (PBV) by cardiovascular magnetic resonance imaging (CMR) is a novel method which may provide a measure of pulmonary congestion and backward failure in heart disease. The aims were to prospectively evaluate the factors contributing to PBV by CMR, and determine whether PBV is higher in patients with left ventricular (LV) measures outside normal limits.

\section{Methods}

1.5T CMR was performed in 119 subjects (98 consecutive clinically referred patients, 21 controls). A subgroup of patients $(\mathrm{n}=37,38 \%)$ were identified by LV measures outside normal limits (Maceira AM, et al, JCMR, 2006; LV end-diastolic volume (LVEDV) index > 100 $\mathrm{ml} / \mathrm{m} 2$, LV ejection fraction (LVEF) $<58 \%$ ). PBV was measured as the product of the pulmonary transit time for an intravenous contrast bolus and cardiac output from CMR phase contrast flow measurement.

\section{Results}

For all subjects, PBV correlated with height $(\mathrm{R} 2=0.31$, $\mathrm{p}<0.001)$, LVEDV $(\mathrm{R} 2=0.23, \mathrm{p}<0.001)$, lung volume $(\mathrm{R} 2=0.20, \mathrm{p}<0.001)$ and age $(\mathrm{R} 2=0.05, \mathrm{p}=0.02$, multivariate adjusted $\mathrm{R} 2=0.44, \mathrm{p}<0.001)$, but not with
LVEF $(\mathrm{R} 2<0.001, \mathrm{p}=0.91)$. Compared to controls (LVEDVi $86 \pm 9 \mathrm{ml} / \mathrm{m} 2$, LVEF $61 \pm 3 \%$ ), the subgroup (LVEDVi $129 \pm 31 \mathrm{ml} / \mathrm{m} 2$, LVEF $39 \pm 11 \%$ ) had a higher PBV (531 \pm 133 vs $463 \pm 91 \mathrm{ml}, \mathrm{p}=0.04)$ but no difference in PBV indexed to lung volume (PBVI, $\mathrm{p}=$ $0.80)$, height $(\mathrm{p}=0.41)$ or lung volume $(\mathrm{p}=0.10)$.

\section{Conclusions}

In a clinical population, only $44 \%$ of the variation in PBV could be explained by height, LVEDV, lung volume and age. Hence, quantification of PBV by CMR is a novel and feasible tool for clinical assessment of patients with heart disease and appears to provide additional information compared to conventional anthropometric and cardiac pumping measures. A subgroup of patients outside LV normal limits had a higher PBV but PBVI was not increased. Prospective evaluation of $\mathrm{PBV}$ in patients with congestive heart failure would be of value.

\section{Funding}

Swedish Research Council, Swedish Heart and Lung Foundation, Stockholm County Council, Karolinska Institutet, Swedish Medical Assocation, Swedish Society of Medical Research, and The Kleberg, Osterman, Wiberg, Erling-Persson, and Grönberg Foundations. 


\section{Authors' details}

'Department of Clinical Physiology, Karolinska Institutet and Karolinska

University Hospital, Stockholm, Sweden. ${ }^{2}$ Department of Clinical Physiology,

Lund University and Lund University Hospital, Lund, Sweden.

Published: 16 January 2014

doi:10.1186/1532-429X-16-S1-P261

Cite this article as: Fredholm et al:: The pulmonary blood volume

measured by cardiovascular magnetic resonance imaging - relation to

cardiac pumping and anthropometric measures. Journal of Cardiovascular

Magnetic Resonance 2014 16(Suppl 1):P261.

Submit your next manuscript to BioMed Central and take full advantage of:

- Convenient online submission

- Thorough peer review

- No space constraints or color figure charges

- Immediate publication on acceptance

- Inclusion in PubMed, CAS, Scopus and Google Scholar

- Research which is freely available for redistribution

Submit your manuscript at www.biomedcentral.com/submit 